06

\title{
Экспериментальное исследование влияния добавки наночастиц оксида кремния на характеристики смачиваемости нефтью горной породы
}

\author{
(C) А.В. Минаков ${ }^{1,2}$, М.И. Пряжников ${ }^{1,2}$, Я.Н. Сулемана ${ }^{1}$, В.Д. Мешкова ${ }^{1}$ \\ ${ }^{1}$ Сибирский фредеральный университет, Красноярск, Россия \\ ${ }^{2}$ Институт теплофиизики им. С.С. Кутателадзе СО РАН, Новосибирск, Россия \\ E-mail: Aminakov@sfu-kras.ru
}

Поступило в Редакцию 20 августа 2020г.

В окончательной редакции 14 сентября 2020 г.

Принято к публикации 15 сентября 2020 г.

\begin{abstract}
Приведены результаты экспериментальных исследований межфазного натяжения и смачиваемости поверхности в системе наноразмерная суспензия/нефть/горная порода. Впервые систематически исследовано влияние концентрации и размера наночастиц оксида кремния на коэффициент межфазного натяжения и значение краевого угла смачивания. Рассмотрены широкие диапазоны массовых концентраций наночастиц (от 0 до 1 wt.\%) и их средних размеров (от 5 до $50 \mathrm{~nm}$ ). Установлено, что использование наносуспензий позволяет радикально менять смачиваемость нефтью горной породы. При этом указанное влияние существенно зависит от концентрации и размеров наночастиц.
\end{abstract}

Ключевые слова: смачиваемость, межфазное натяжение, наносуспензия, увеличение нефтеотдачи.

DOI: 10.21883/PJTF.2020.24.50425.18520

Нефтегазовая индустрия является одной из важнейших отраслей экономики России. Для ее устойчивого развития важно рационально использовать уже существующие месторождения, а также необходима разведка новых. Особое внимание следует уделить уровню обводненности на действующих месторождениях, который в настоящее время составляет 70-80\%. Наблюдаемая тенденция показывает, что без внедрения новых высокоэффективных технологий добыча нефти будет снижаться и ввод новых месторождений не сможет компенсировать это падение. Для решения данной проблемы могут использоваться нанотехнологии, направленные на увеличение нефтеотдачи.

В последние годы появились лабораторные исследования, в которых показано, что применение наносуспензий в качестве вытесняющих жидкостей для заводнения пласта позволяет существенно повысить коэффициент извлечения нефти (КИН) [1-4]. Так, в работе [2] продемонстрировано, что добавление $1 \mathrm{wt} \%$ наночастиц оксида кремния позволяет увеличить КИН на 30\% (по сравнению с водой). Близкие по величине приращения КИН были получены при заводнении с помощью наносуспензий с металлическими наночастицами [3] и наночастицами оксида титана [4].

В качестве одной из возможных причин влияния добавок наночастиц на нефтеотдачу называют изменение смачиваемости горной породы, которое способствует вымыванию как пленочной, так и капиллярноудержанной нефти [1,4-6]. В настоящей работе проведены экспериментальные исследования межфазного натяжения и смачиваемости поверхности в системе наносуспензия/нефть/горная порода. Впервые система- тически исследовано влияние концентрации и размера наночастиц оксида кремния на коэффициент межфазного натяжения и значение краевого угла смачивания.

В экспериментах использовалась легкая нефть со следующими характеристиками: плотность нефти равна $0.831 \mathrm{~g} / \mathrm{cm}^{3}$, вязкость $0.0078 \mathrm{~Pa} \cdot \mathrm{s}$. В качестве образца горной породы использовался доломит. Наносуспензии были приготовлены на основе дистиллированной воды. Были использованы порошки наночастиц $\mathrm{SiO}_{2}$ (ООО „Бардаханов“, Новосибирск). Средний размер наночастиц варьировался от 5 до $50 \mathrm{~nm}$. Концентрация наночастиц варьировалась от 0 до 1 wt.\%. Для приготовления наносуспензии применялся стандартный двухшаговый метод. Необходимое количество порошка добавляется в жидкость, после чего полученная суспензия тщательно механически перемешивается. Для разрушения конгломератов наночастиц суспензии подвергаются обработке в ультразвуковом диспергаторе „Волна-М“.

Измерение межфазного натяжения и краевого угла смачивания проводилось с помощью автоматического тензиометра IFT-820-P. Принцип действия тензиометра IFT-820-Р основан на методе висячей капли, при котором поверхностное натяжение определяется по результатам измерений геометрических параметров капли исследуемой жидкости. Обработка результатов измерений выполнена с использованием программного обеспечения DropImage Advanced. Детальное описание метода определения межфазного натяжения можно найти в работе [7]. Итоговые данные получены осреднением по четырем независимым измерениям. Разброс данных в экспериментах не превышал 5\%. Методика измерений коэффициента поверхностного натяжения была проте- 


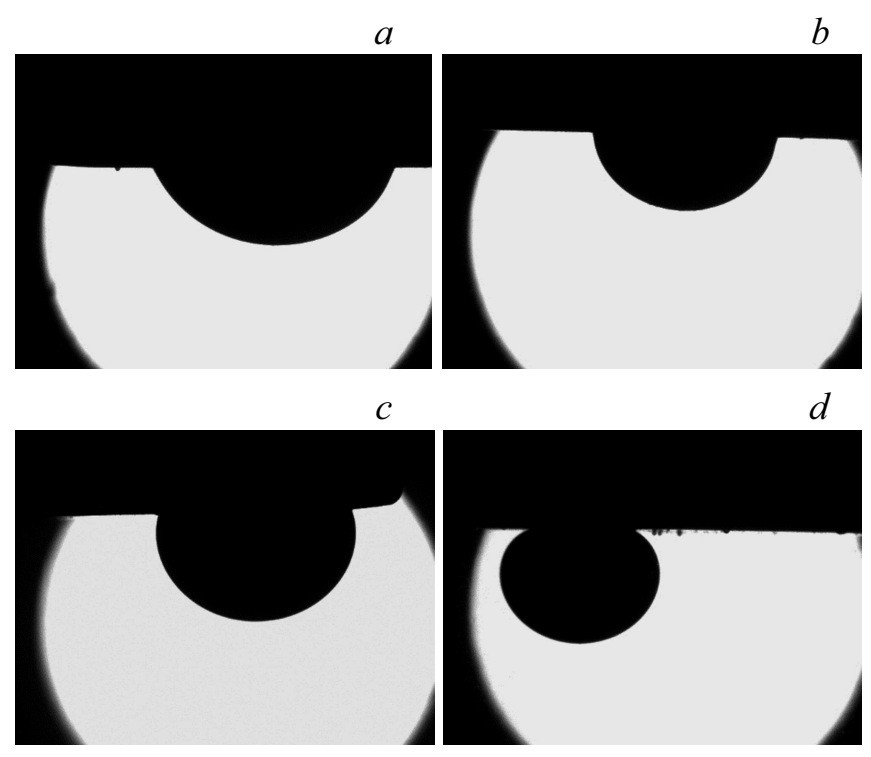

Рис. 1. Фотографии капли нефти в наносуспензии $\mathrm{SiO}_{2}(5 \mathrm{~nm})$ на поверхности доломита при концентрации наночастиц, равной $0(a), 0.25(b), 0.5(c)$ и 1 wt.\% $(d)$.

стирована на воде и этиленгликоле. Получено хорошее согласие с эталонными данными.

При проведении экспериментов использовалась следующая последовательность действий. В герметичной ячейке на специальном штоке крепился образец горной породы, который представлял собой прямоугольную подложку размером $1 \times 1 \mathrm{~cm}$. После этого ячейка заполнялась исследуемой наножидкостью, герметизировалась и выдерживалась при стандартных условиях в течение $2 \mathrm{~h}$. Далее через тонкий капилляр в нижней части ячейки вводилась капля нефти, которая всплывала и ложилась на подложку (рис. 1). После установления равновесия фиксировалось значение краевого угла.

Сначала проведено исследование влияния концентрации наночастиц на краевой угол на границе наносуспензия/нефть/горная порода. На рис. 1 показаны типичные результаты измерений для наножидкости с частицами $\mathrm{SiO}_{2}$ со средним размером $5 \mathrm{~nm}$. Как видно из фотографий, добавка наночастиц радикально влияет на смачивание нефтью горной породы в наносуспензии. Было установлено, что добавка наночастиц в жидкость существенно ухудшает смачиваемость нефтью горной породы. Фактически добавка $1 \mathrm{wt} . \%$ наночастиц в воду делает доломит несмачиваемым нефтью. Зависимость краевого угла смачивания (внутреннего) от концентрации наночастиц $\mathrm{SiO}_{2}$ со средним размером $5 \mathrm{~nm}$ приведена на рис. 2. С увеличением концентрации наночастиц до 0.5 wt.\% краевой угол возрастает с 73 до $153^{\circ}$. Дальнейшее увеличение концентрации наночастиц, как видно, не приводит к изменению смачиваемости.

На следующем этапе было проведено исследование влияния концентрации наночастиц на межфазное натяжение на границе раздела наносуспензия/нефть. На рис. 3 показаны результаты измерений для наножидкости с частицами оксида кремния со средним размером $5 \mathrm{~nm}$. В результате исследований было установлено, что с увеличением концентрации наночастиц межфазное натяжение в целом снижается (рис. 3), хотя и немонотонно. Для данного размера наночастиц максимальное снижение межфазного натяжения составляет около 7\%.

Далее исследовано влияние размера наночастиц на характеристики смачиваемости нефтью горной породы в наносуспензии. Для этого рассмотрена добавка в воду наночастиц оксида кремния со средними размерами 5, 18, 22 и $50 \mathrm{~nm}$. Определение средних размеров наночастиц в суспензиях выполнено с помощью акустического спектрографа DT-1200. Массовая концентрация наночастиц в измерениях была равна 0.5 wt.\%.

Результаты измерений краевого угла смачивания и межфазного натяжения приведены в таблице. Результаты экспериментов показывают, что размер наночастиц также оказывается значимым фактором влияния на межфазное натяжение и особенно на краевой угол смачивания поверхности нефтью. Анализ полученных данных позволяет выделить следующие закономерности: с уменьшением размера наночастиц краевой угол смачивания на границе нефть/наносуспензия/горная порода

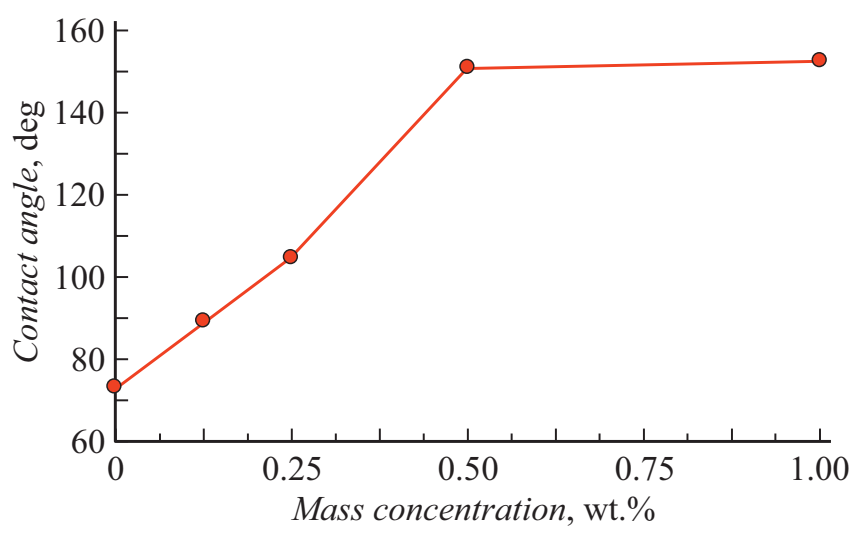

Рис. 2. Зависимость краевого угла смачивания наносуспензия/нефть на доломите от концентрации наночастиц $\mathrm{SiO}_{2}$.

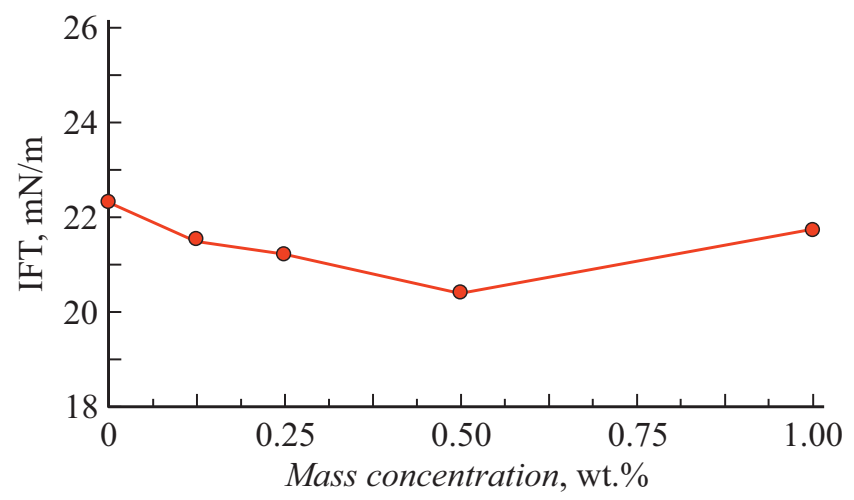

Рис. 3. Зависимость межфазного натяжения (IFT) на границе раздела наносуспензия/нефть от концентрации наночастиц $\mathrm{SiO}_{2}$. 
Краевой угол смачивания наносуспензия/порода и межфазное натяжение капли нефти в наносуспензии с разным размером наночастиц $\mathrm{SiO}_{2}$

\begin{tabular}{c|c|c}
\hline Размер частиц, nm & $\begin{array}{c}\text { Краевой угол } \\
\text { смачивания, }^{\circ}\end{array}$ & $\begin{array}{c}\text { Коэффициент } \\
\text { межфазного } \\
\text { натяжения, } \mathrm{mN} / \mathrm{m}\end{array}$ \\
\hline 5 & 151 & 20.4 \\
18 & 117 & 19.3 \\
22 & 109 & 17.1 \\
50 & 91 & 15.6
\end{tabular}

увеличивается; при больших концентрациях наночастиц влияние размера наночастиц пропадает. Таким образом, с уменьшением размера наночастиц способность отмывать от нефти у наносуспензии возрастает. Из этого следует, что для увеличения нефтеотдачи эффективнее использовать частицы с минимальным размером.

Средний размер наночастиц также оказывает значительное влияние и на межфазное натяжение на границе нефть/наносуспензия. В результате экспериментов было установлено, что с увеличением размера наночастиц межфазное натяжение уменьшается. Так, при увеличении среднего размера частиц с 5 до $50 \mathrm{~nm}$ натяжение снижается примерно в 1.3 раза.

$\mathrm{C}$ точки зрения увеличения нефтеотдачи в большинстве случаев выгодно снижение межфазного натяжения, т.е. в этом смысле более выгодно использовать частицы с максимальным размером. Однако при этом, как было установлено, снижается влияние наночастиц на смачиваемость. Поэтому должен существовать некоторый оптимальный размер наночастиц, при котором увеличение КИН при фиксированной концентрации будет максимальным.

Таким образом, в работе установлено, что использование наносуспензий позволяет радикально менять смачиваемость нефтью горной породы. При этом данное влияние сложным образом зависит от концентрации и размеров наночастиц. Это открывает широкие перспективы применения наночастиц для интенсификации нефтеотдачи при заводнении пласта.

\section{Финансирование работы}

Исследование выполнено при финансовой поддержке Российского научного фонда в рамках проекта № 17-79-20218-П.

\section{Конфликт интересов}

Авторы заявляют, что у них нет конфликта интересов.

\section{Список литературы}

[1] Евдокимов И.Н. „Наножидкости“ и „умные жидкости“ в технологиях разработки нефтегазовых месторождений. М.: Недра, 2016. 246 с.

[2] Roustaei A., Bagherzadeh H. // J. Petrol. Explor. Prod. Technol. 2015. V. 5. N 1. P. 27-33.

[3] Suleimanov B.A., Ismailov F.S., Veliyev E.F. // J. Petrol. Sci. Eng. 2011. V. 78. N 2. P. 431-437.

[4] Ehtesabi H., Ahadian M.M., Taghikhani V. // Energy Fuels. 2015. V. 29. N 1. P. $1-8$.

[5] Питюк Ю.А., Сематов С.Л., Муллаянов А.И., Абрамова O.A. // Письма в ЖТФ. 2019. Т. 45. В. 23. С. 26-29.

[6] Кочоридзе С.И., Левин Ю.К. // ЖТФ. 2020. Т. 90. В. 6. C. 886-890.

[7] Berry J.D., Neeson M.J., Dagastine R.R., Chance D.Y.C., Tabor R.F. // J. Colloid Interface Sci. 2015. V. 454. P. 226237. 